\title{
Effect of sub-lethal lead exposure at different salinities on osmoregulation and hematological changes in tilapia, Oreochromis niloticus
}

\author{
Ma'dan Haikal Adhim, Ahmad Zainuddin, Trisnadi Widyaleksono Catur Putranto, \\ Bambang Irawan, Agoes Soegianto
}

Received - 08 April 2017/Accepted - 16 August 2017. Published online: 30 September 2017; @Inland Fisheries Institute in Olsztyn, Poland Citation: Adhim M.H., Zainuddin A., Putranto T.W.C., Irawan B., Soegianto A. 2017 - Effect of sub-lethal lead exposure at different salinities on osmoregulation and hematological changes in tilapia, Oreochromis niloticus - Arch. Pol. Fish. 25: 173-185.

\begin{abstract}
The objectives of this study were to evaluate the effects of sub-lethal lead concentrations on serum osmolality, $\mathrm{Na}^{+}$and $\mathrm{Cl}^{-}$levels, and hematological parameters in Nile tilapia, Oreochromis niloticus (L.) at different salinity levels. The serum osmolalities (SO) were not significantly different at any of the salinity levels in the control fish, while in $\mathrm{Pb}$-exposed fish the $\mathrm{SO}$ increased with increasing salinity. The concentrations of serum $\mathrm{Na}^{+}$and $\mathrm{Cl}^{-}$in both the control and $\mathrm{Pb}$-exposed fish increased with increasing salinity. The levels of red blood cells (RBC), hemoglobin $(\mathrm{Hb})$, and hematocrit (Ht) in the control fish were not significantly different at any of the salinity levels. Meanwhile, the levels of RBC, $\mathrm{Hb}$, and $\mathrm{Ht}$ in $\mathrm{Pb}$-exposed fish increased with increasing salinity levels. The levels of RBC (at 0 and 5 ppt) and Ht (at 0, 5 and 10 ppt) in $\mathrm{Pb}$-exposed fish were lower than in the control fish. The levels of $\mathrm{Hb}$ in $\mathrm{Pb}$-exposed fish were lower than in the control fish at all salinity levels. The levels of WBC in the control fish increased with increasing salinity, while its levels in the $\mathrm{Pb}$-exposed fish decreased with increasing salinity. The levels of WBC in the $\mathrm{Pb}$-exposed fish were higher than in the control fish at 0 and 5 ppt.
\end{abstract}

Keywords: fish, $\mathrm{Pb}$, blood, erythrocytes, leukocytes, ion

\footnotetext{
M.H. Adhim, A. Zainuddin, T.W.C. Putranto, B. Irawan, A. Soegianto [ $\left.\Xi^{\circ}\right]$ Department of Biology, Faculty of Sciences and Technology,

Universitas Airlangga, Surabaya, Indonesia

e-mail: agoes_soegianto@unair.ac.id
}

\section{Introduction}

Heavy metals are present naturally in the environment; however, as a consequence of industrial, agricultural, and anthropogenic activities levels of them are increasing rapidly. Heavy metals at high concentrations can cause hazardous effects to many aquatic organisms by changing genetic, metabolic, physiological, biochemical, and behavioral parameters (Scott and Sloman 2004, Atli and Canli 2007, Ramesh et al. 2009). Lead (Pb) is a toxic metal that is still a potential problem in aquatic systems because it comes from ore processing, smelting, refining operations, coal burning, cement manufacturing, agricultural runoff, industrial and domestic waste water effluents, and its in gasoline, batteries and paints (Scott and Sloman 2004, Aldoghachi et al. 2015).

The toxic effects of heavy metals depend on a wide range of environmental factors, among which salinity is one of the most important (Erickson et al. 2008). The toxicity of metal decreases as the salinity of the media increases. This inverse relationship is usually explained by increasing free metal ion concentrations with increasing salinity. Free metal ions are the most bioavailable form of metals to aquatic organism (Rainbow 1995). Salinity affects metal

\footnotetext{
C Copyright by Stanisław Sakowicz Inland Fisheries Institute in Olsztyn.

(C) 2017 Author(s). This is an open access article licensed under the Creative Commons Attribution-NonCommercial-NoDerivs License (http://creativecommons.org/licenses/by-nc-nd/3.0/).
} 
bioavailability and uptake and its subsequent toxicity by competing with metal ions binding to biological molecules (Erickson et al. 2008, Loro et al. 2012).

Because of their tolerance of a wide range of salinity levels (from 0 to $32 \mathrm{ppt}$ ), various tilapia strains can be cultured efficiently in freshwater, brackish water, and seawater (Suresh and Lin 1992, Avella et al. 1993). However, Baroiller et al. (2000) reported that Nile tilapia, Oreochromis niloticus (L.), do not tolerate salinity above $20 \mathrm{ppt}$ and might not be suitable for culture in full-strength seawater (37 to 40 ppt). Under natural and culture conditions, tilapia often encounter both water salinity changes and elevated levels of heavy metals, which renders the interaction between salinity acclimation and toxicant response important (Adeyemi et al. 2012). As a consequence of salinity fluctuations, tilapia typically possess highly developed mechanisms for ion regulation. O. niloticus is a hyper- and hypo-osmoregulator, thus, at low salinities it actively maintains its blood hyper-osmotic to the external environment, while at high salinities the blood is maintained in a hypo-osmotic state (Fontainhas-Fernandes et al. 2003). As a result, osmo- and ion-regulatory processes occur in order to maintain the homeostasis of the organism (Roast et al. 2001).

The gill is the primary site of osmotic and ionic regulation in fish, but unfortunately it serves as the primary target for the toxic action of various metals (Evans et al. 2005). Metals affect the osmoregulation of various fishes, for example, copper impaired branchial ion-regulation of freshwater rainbow trout by inhibiting both the active transport of $\mathrm{Na}^{+}$and $\mathrm{Cl}^{-}$ and increasing the ionic permeability of the gills, which resulted in a net loss of these ions (Lauren and McDonald 1985, 1986). Spry and Wood (1985) report that zinc increased $\mathrm{Na}^{+}$and $\mathrm{Cl}^{-}$effluxes, and Verbost et al. (1987) demonstrated that cadmium increased $\mathrm{Ca}^{2+}$ efflux. Lock et al. (1981) demonstrated increased osmotic permeability to water of the gills after exposure to mercury. A neotropical fish, Prochilodus lineatus, exposed to lead showed a decrease in $\mathrm{Na}^{+}$plasma concentration (Martinez et al. 2004). These passive movements occurred due to increased branchial permeability (Wendelaar Bonga and Lock 1992).

Changes in both water salinity and heavy metal level can also trigger alteration in blood composition and immune mechanisms. Witeska (2005) demonstrated that the red blood cell system of fish reacted to heavy metal intoxication with anemia; however, in some cases, particularly after brief exposure, red blood parameters (hematocrit, red blood cell, mean corpuscular volume, hemoglobin) can increase. Heavy metal intoxication also reduces the white blood cell count, particularly that of lymphocytes (Witeska 2005). This is usually accompanied by the impairment of their activities (Viale and Calamari 1984, Khangarot and Tripathi 1991, Viola et al. 1996). The aim of present study was to evaluate the effects of sub-lethal lead exposure on serum osmolality, ion levels, and the hematological parameters of tilapia, $O$. niloticus, at different salinity levels.

\section{Materials and methods}

\section{Fish acclimation}

O. niloticus (East Java strain, local name: Jatimbulan) (approximately $13.1 \pm 0.4 \mathrm{~cm}$ total length; $25.4 \pm 0.5 \mathrm{~g}$ body weight) were collected from a commercial farm in Pasuruan, East Java, Indonesia. They were transported to the laboratory and acclimated for adaptation for two weeks to different salinities: $0,5,10,15$, and $20 \mathrm{ppt}$ with a 5 ppt daily increase in order to avoid osmotic shock. They were fed twice a day with commercial pellets at libitum. During acclimation, high mortality was observed at $20 \mathrm{ppt}$; hence, the fish were acclimated at salinities 0 , 5,10 , and 15 ppt for an additional 14 days, respectively. Salinity was measured using a hand held salinity refractometer (Atago, Japan). Seawater was obtained from the coast adjacent to the university, and freshwater was obtained from municipal tap water. Before being used for acclimation and experimentation, the tap water was aerated overnight to accelerate dechlorination (Putranto et al. 2014). 
Freshwater and diluted seawaters were filtered through gravel, sand, and sponge filters. Throughout the acclimation and experimentation tests, water temperature was measured using glass mercury thermometers $\left({ }^{\circ} \mathrm{C}\right), \mathrm{pH}$ was measured with a $\mathrm{pH}$ meter (Hanna Model HI 981502, China), and dissolved oxygen (DO) was measured with a DO meter (Lutron DO 5510, Taiwan). The values of water temperature, $\mathrm{pH}$, and dissolved oxygen were $28-30^{\circ} \mathrm{C}, 7.55-8.05$, and 7.1-7.6 $\mathrm{mg} \mathrm{L}^{-1}$, respectively, with a natural photoperiod.

\section{$\mathrm{LC}_{50}$ assessment}

The median lethal concentration $\left(\mathrm{LC}_{50}\right)$ of $\mathrm{Pb}$ in tilapia was applied only to fish acclimated in freshwater $(0 \mathrm{ppt})$. The $\mathrm{LC}_{50}$ value was then used as the basis for establishing sub-lethal $\mathrm{Pb}$ concentrations for the next experiment. A stock solution (1000 mg $\left.\mathrm{Pb} \mathrm{L}{ }^{-1}\right)$ was prepared from $1.5985 \mathrm{~g}$ of $\mathrm{Pb}\left(\mathrm{NO}_{3}\right)_{2}$ (Merck, Germany) in $1000 \mathrm{ml}$ of deionized water. Selected experimental concentrations were made by adding adequate volumes of the stock solution to freshwater. A toxicity range-finding test was conducted prior to initiating a static, acute, definitive toxicity test. The definitive toxicity test was conducted in $63 \mathrm{~L}$ plastic tanks containing $50 \mathrm{~L}$ of test solution. Each tank contained ten fish, and the media was aerated continuously with an air stone, but it was not renewed. The fish were starved for $24 \mathrm{~h}$ before the toxicity test. The nominal test $\mathrm{Pb}$ concentrations used for acute toxicity estimations were $0,50,100$, 200, 400, and $800 \mathrm{mg} \mathrm{L}^{-1}$. Three replicates were performed for all treatments and for control groups. Each day, dead fish were counted and removed from the tanks. The fish were not fed during the experiment. Death was confirmed when the animals were immobile, lacked opercular movement, and showed no response when touched with a glass rod. The data from the experiment were used to estimate the median lethal concentration (96 $\mathrm{h} \mathrm{LC}_{50}$ ) using the trimmed Spearman-Karber method. The $96 \mathrm{~h} \mathrm{LC}_{50}$ and $95 \%$ confidence intervals of $\mathrm{Pb}$ to $O$. niloticus were 200 (170.84-234.14) $\mathrm{mg} \mathrm{L}^{-1}$. The sub-lethal
Table 1

Percentage mortality (\%) of $O$. niloticus exposed to $\mathrm{Pb}$ in freshwater (0 ppt salinity) for $96 \mathrm{~h}$ and its medium lethal concentration ( $\mathrm{LC}_{50}$ with $95 \%$ confidence limits) calculated with the trimmed Spearman-Karber method

\begin{tabular}{lll}
\hline \hline $\begin{array}{l}\text { Lead concentra- } \\
\text { tion }\left(\mathrm{mg} \mathrm{Pb} \mathrm{L}^{-1}\right)\end{array}$ & $\begin{array}{l}\text { Percentage } \\
\text { mortality }(\%)\end{array}$ & $\begin{array}{l}\mathrm{LC}_{50} \text { with 95\% } \\
\text { confidence limits } \\
\left(\mathrm{mg} \mathrm{Pb} \mathrm{L}^{-1}\right)\end{array}$ \\
\hline \hline 0 & 0 & \\
50 & 0 & \\
100 & 13.3 & $200(170.84-234.14)$ \\
200 & 40 & \\
400 & 96.7 & \\
800 & 100 & \\
\hline \hline
\end{tabular}

toxicity of this experiment was $100 \mathrm{mg} \mathrm{Pb} \mathrm{L}^{-1}(\approx 50 \%$ of $\mathrm{LC}_{50}$ ) (Table 1 ).

\section{Sub-lethal effect on serum osmolality, ions, and hematological parameters}

Sub-lethal tests were conducted using the static renewal method, with $80 \%$ test solutions renewed every $48 \mathrm{~h}$. The fish were exposed for $7 \mathrm{~d}$ to sub-lethal concentrations of $\mathrm{Pb}: 0$ (control) and $100 \mathrm{mg} \mathrm{L}^{-1}$, at salinities of $0,5,10$, and 15 ppt. There were triplicates for each test media, with a total of five fish per replicate. Test media were aerated continuously. During the tests, the fish were fed with commercial fish food twice a day at libitum. Uneaten food and debris were removed daily.

At the end of the exposure period, five fish were chosen at random and removed from each treatment for determinations of serum osmolality, serum ions, and hematological parameters. Prior to blood sampling, the fish were anesthetized with $200 \mathrm{mg} \mathrm{L}^{-1}$ clove solution (Mohseni et al. 2008). Blood from each fish was obtained by puncturing the heart using a sterile plastic syringe. Then, blood samples were introduced immediately to tubes containing ethylenediamine tetraacetic acid (EDTA) as an anti-coagulating agent for the assessment of hematological parameters, and to non-EDTA tubes for the assessment of serum osmolalities and serum ions. 
Blood samples from non-EDTA tubes were centrifuged at $4500 \times \mathrm{g}$ for $10 \mathrm{~min}$ to separate blood serum and blood cells (at ambient temperature). The serum was then measured for osmolality and $\mathrm{Na}^{+}$and $\mathrm{Cl}^{-}$concentrations. Serum osmolality was measured using an automated freezing point depression osmometer (Fiske ${ }^{\circledR} 210$ Micro-Sample Osmometer, USA). The osmolality of serum samples is expressed as $\mathrm{mOsm} \mathrm{kg}^{-1}$. The medium from each treatment was also sampled and its osmolality was determined using the same osmometer. Serum ions $\mathrm{Na}^{+}$and $\mathrm{Cl}^{-}$ were measured with the potentiometic (ion-selective electrode) method using an automated electrolyte analyzer (Jokoh EX-D, Japan). Blood samples from EDTA tubes were aspirated directly with an automated hematology analyzer (Sysmex XT-2000i, Japan) to assess hematological parameters (the red blood cell (RBC) count, hematocrit (Ht), hemoglobin (Hb) concentration, and white blood cell (WBC) count)). The Sysmex XT-2000i uses the electric resistance detecting method (impedance technology) with hydrodynamic focusing to measure RBC counts and Ht. Fluorescence flow cytometry is used to measure WBC. Hb is measured photocolorimetrically using sodium lauryl sulfate- $\mathrm{Hb}$, a cyanide-free method. The reagents required for operating the Sysmex XT-2000i were obtained from Sysmex Corporation.

\section{Statistical analysis}

All data were expressed as mean \pm standard deviation, and their normality and homogeneity were verified before using them for statistical analysis. To determine the exposure effects of $\mathrm{Pb}$, salinity and its impact on osmolalities, ion levels, and hematological parameters were analyzed using two-way ANOVA, respectively. When significant differences were detected $(\mathrm{P} \leq 0.05)$, Duncan's multiple range test was employed for multiple comparisons to determine which treatment had a significant effect on osmolalities, ion levels, and hematological parameters at a significance level of 0.05 .

\section{Results}

\section{$\mathrm{LC}_{50}$ assessment}

No fish died in the control treatments. Mortality increased with increasing $\mathrm{Pb}$ concentration. Mortalities of $100 \%$ were observed for fish exposed to $800 \mathrm{mg} \mathrm{Pb}$ $\mathrm{L}^{-1}$. The $96 \mathrm{~h} \mathrm{LC}_{50}$ with $95 \%$ confidence limits was 200 (170.84-234.14) mg Pb L-1 (Table 1).

\section{Serum osmolality}

No fish mortality was noted during the experiments. There was no significant $\mathrm{Pb}$ effect $(\mathrm{P}=0.179)$ or interactive effect between salinity and $\mathrm{Pb}(\mathrm{P}=0.460)$ on the SO of O. niloticus. However, the effect of salinity on $\mathrm{SO}(\mathrm{P}=0.003)$ (Table 2$)$ was significant. Duncan's test revealed that the SO values of $O$. niloticus at salinity levels of $0,5,10$, and $15 \mathrm{ppt}$ without $\mathrm{Pb}$-exposure were not significantly different $(\mathrm{P}>$ 0.05). In Pb-exposed fish, the highest value of $\mathrm{SO}$ was noted in fish exposed to $100 \mathrm{mg} \mathrm{Pb} \mathrm{L}^{-1}$ at a salinity level of $15 \mathrm{ppt}$, and the lowest SO was observed at 0 ppt. The levels of $\mathrm{SO}$ of $\mathrm{Pb}$-exposed fish at 0 and 5 ppt were not significantly different $(\mathrm{P}>0.05)$. There were no significant differences between the $\mathrm{SO}$ of control and $\mathrm{Pb}$-exposed fish at the same salinity $(\mathrm{P}>$ 0.05) (Figure 1).

\section{Serum ions concentration}

This experiment showed the significant effects of salinity, $\mathrm{Pb}$, and the interaction between salinity and $\mathrm{Pb}$ on serum $\mathrm{Na}^{+}(\mathrm{P}=0.000)$ and $\mathrm{Cl}^{-}$levels in fish $(\mathrm{P}=0.000)$ (Table 2) respectively. The serum $\mathrm{Na}^{+}$and $\mathrm{Cl}^{-}$concentration in $O$. niloticus at different salinity levels both with and without $\mathrm{Pb}$-exposure are presented in Figures 2 and 3, respectively. The concentrations of serum $\mathrm{Na}^{+}$ and $\mathrm{Cl}^{-}$in fish at salinity levels 0 and 5 ppt without $\mathrm{Pb}$ were not significantly different $(\mathrm{P}>0.05)$; however, these levels were significantly lower than those at salinity levels of 10 and 15 ppt $(\mathrm{P} \leq 0.05)$, respectively. Serum $\mathrm{Na}^{+}$and $\mathrm{Cl}^{-}$concentrations in fish at salinity levels 


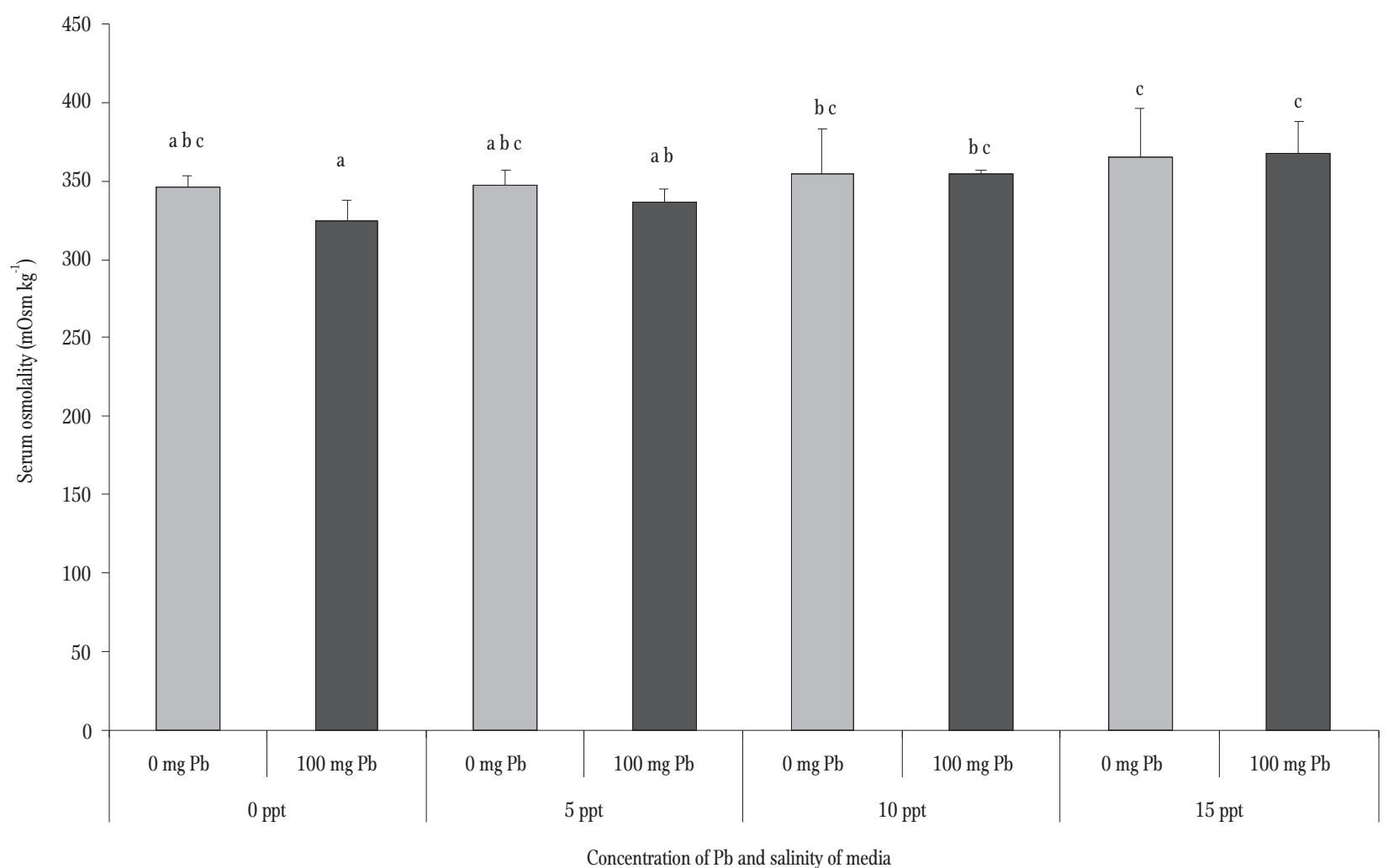

Figure 1. Serum osmolality of $O$. niloticus exposed to 0 and $100 \mathrm{mg} \mathrm{Pb} \mathrm{L}^{-1}$ under different salinities for $7 \mathrm{~d}$. Groups with different letters indicate significant differences $(\mathrm{P}<0.05, \mathrm{a}<\mathrm{b}<\mathrm{c})$. Data are means of five determinations.

Table 2

Two-way ANOVA of serum osmolality, ions, and hematological parameters of $O$. niloticus after $7 \mathrm{~d}$ of exposure to $\mathrm{Pb}$ and salinity treatments $(n=5)$

\begin{tabular}{llll}
\hline \hline Dependent variable & Source & $\mathrm{F}$ & $\mathrm{P}$ \\
\hline \hline Serum osmolality & Salinity & 5.897 & 0.003 \\
& $\mathrm{~Pb}$ & 1.889 & 0.179 \\
Serum $\mathrm{Na}+$ & Salinity $\times \mathrm{Pb}$ & 0.883 & 0.460 \\
& Salinity & 58.751 & 0.000 \\
& $\mathrm{~Pb}$ & 24.295 & 0.000 \\
Serum $\mathrm{Cl}^{-}$ & Salinity $\times \mathrm{Pb}$ & 9.095 & 0.000 \\
& Salinity & 58.121 & 0.000 \\
& $\mathrm{~Pb}$ & 32.597 & 0.000 \\
Red blood cell count & Salinity $\times \mathrm{Pb}$ & 12.366 & 0.000 \\
& Salinity & 12.088 & 0.000 \\
& Pb & 55.286 & 0.000 \\
Hemoglobin & Salinity $\times \mathrm{Pb}$ & 8.170 & 0.000 \\
& Salinity & 20.110 & 0.000 \\
\multirow{3}{*}{ Hematocrit } & Pb & 188.938 & 0.000 \\
& Salinity $\times \mathrm{Pb}$ & 14.110 & 0.000 \\
White blood cell count & Salinity & 49.515 & 0.000 \\
& Pb & 208.991 & 0.000 \\
& Salinity $\times \mathrm{Pb}$ & 38.465 & 0.000 \\
& Salinity & 2.878 & 0.177 \\
& Pb & 1.903 & 0.051 \\
\hline \hline
\end{tabular}




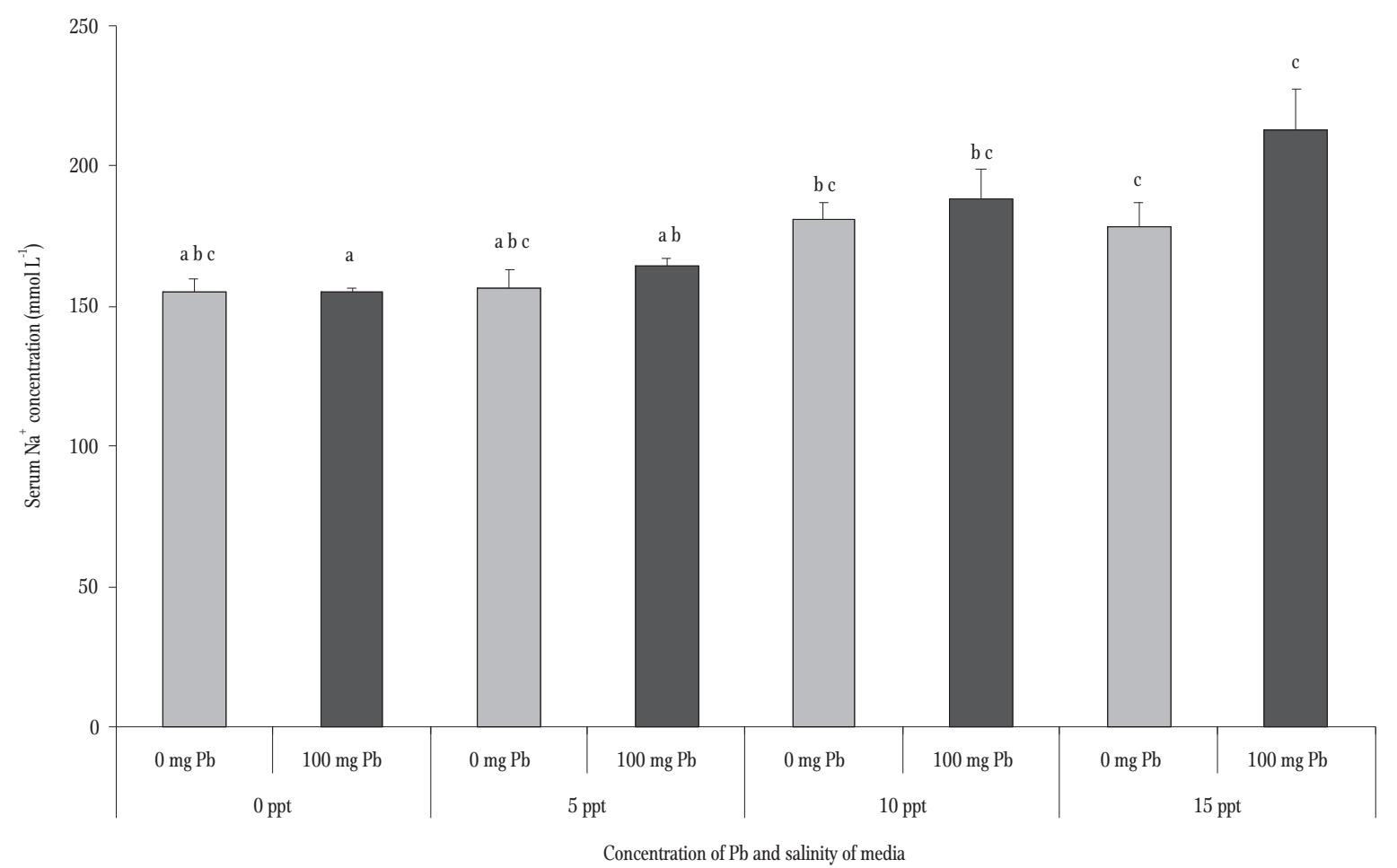

Figure 2. Serum $\mathrm{Na}^{+}$concentrations of $O$. niloticus after exposure to $\mathrm{Pb}\left(0,100 \mathrm{mg} \mathrm{Pb} \mathrm{L}^{-1}\right)$ at different salinities for $7 \mathrm{~d}$. Groups with different letters indicate significant differences $(\mathrm{P}<0.05, \mathrm{a}<\mathrm{b}<\mathrm{c})$. Data are means of five determinations.

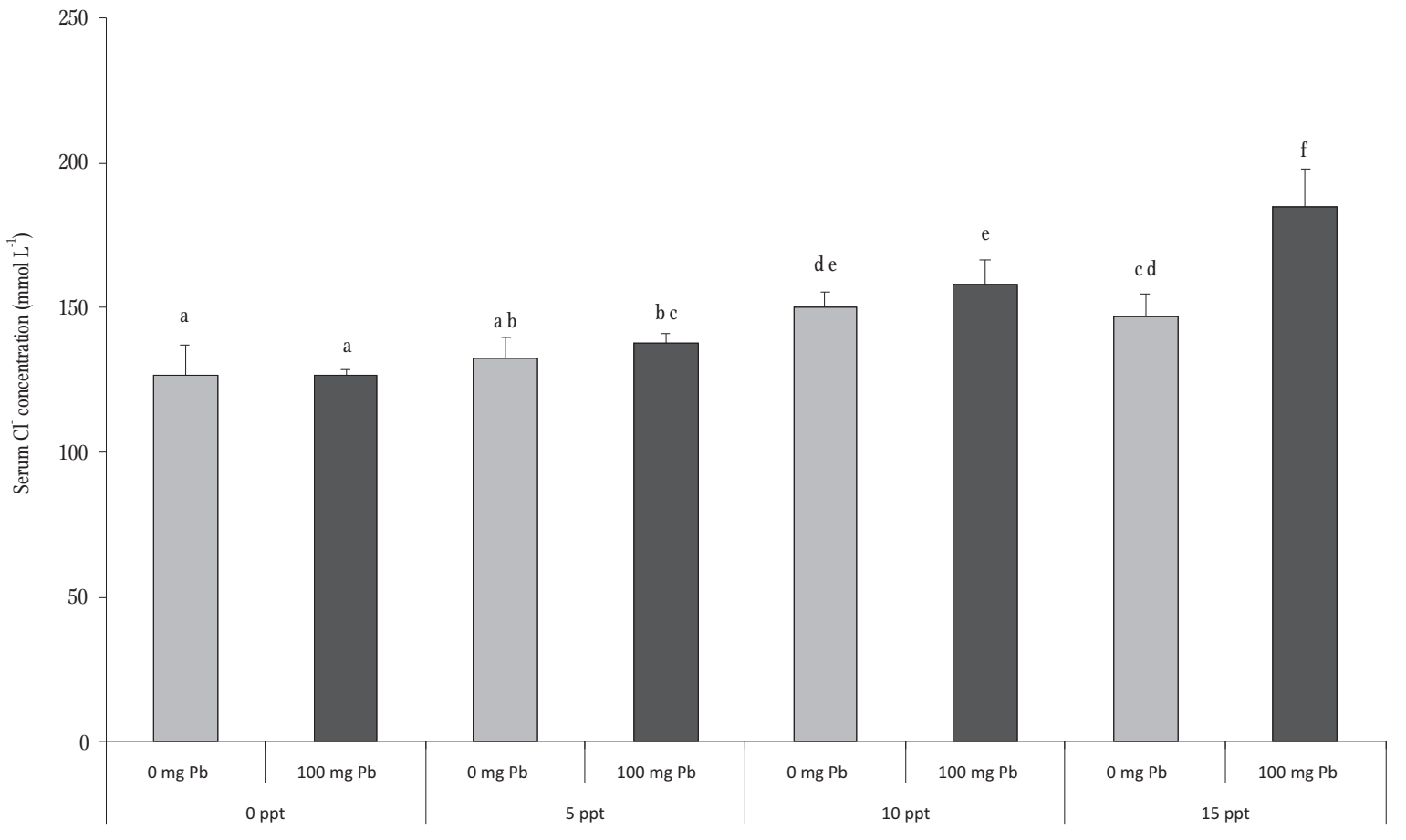

Concentration of $\mathrm{Pb}$ and salinity of media

Figure 3. Serum $\mathrm{Cl}^{-}$concentrations of $O$. niloticus after exposure to $\mathrm{Pb}\left(0,100 \mathrm{mg} \mathrm{Pb} \mathrm{L}{ }^{-1}\right)$ at different salinities $7 \mathrm{~d}$. Groups with different letters indicate significant differences $(\mathrm{P}<0.05, \mathrm{a}<\mathrm{b}<\mathrm{c}<\mathrm{d}<\mathrm{e}<\mathrm{f})$. Data are means of five determinations. 


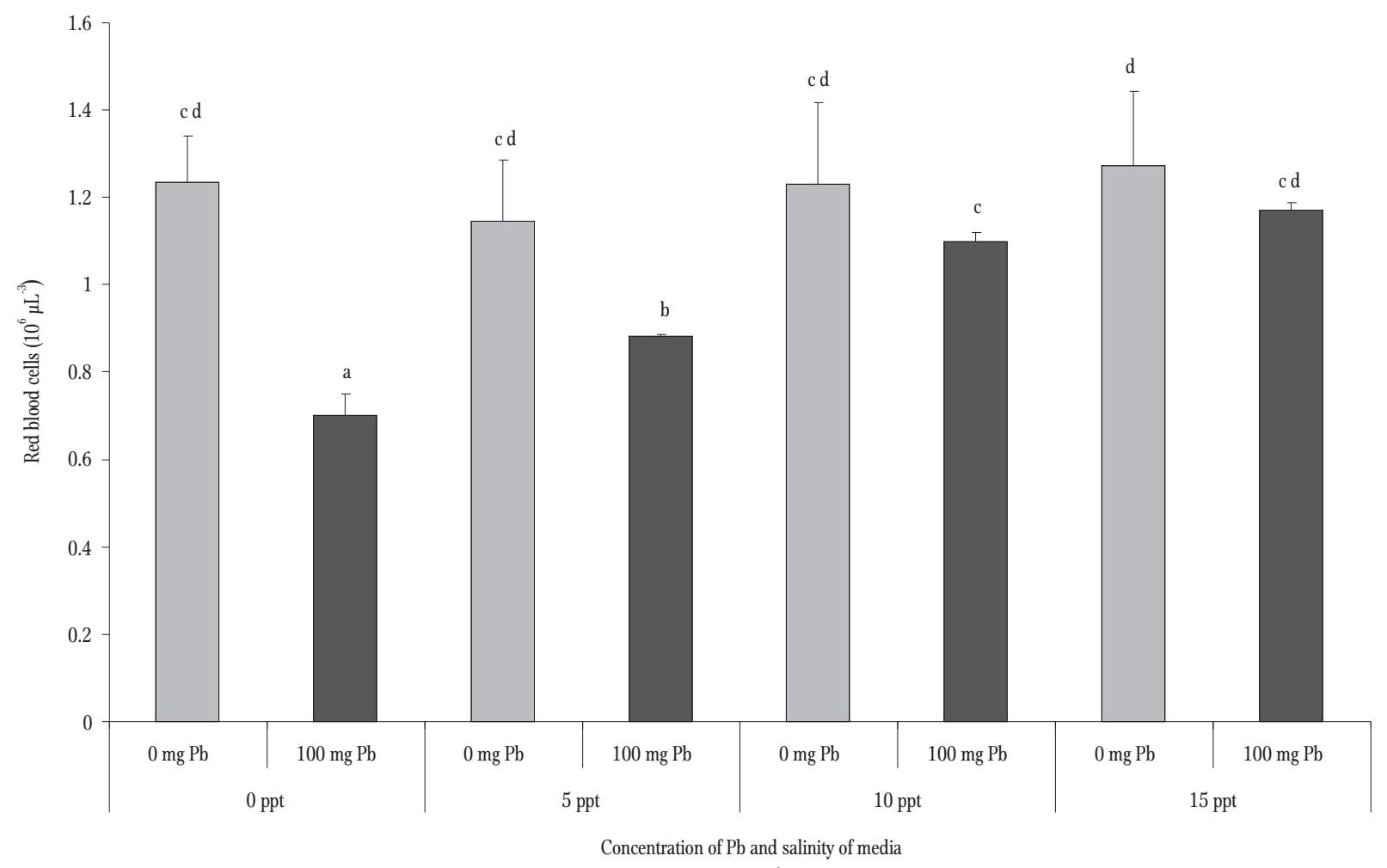

Figure 4. Red blood cells of $O$. niloticus after exposure to $\mathrm{Pb}\left(0,100 \mathrm{mg} \mathrm{Pb} \mathrm{L}^{-1}\right)$ at different salinities 7 d. Groups with different letters indicate significant differences $(\mathrm{P}<0.05, \mathrm{a}<\mathrm{b}<\mathrm{c}<\mathrm{d})$. Data are means of five determinations.

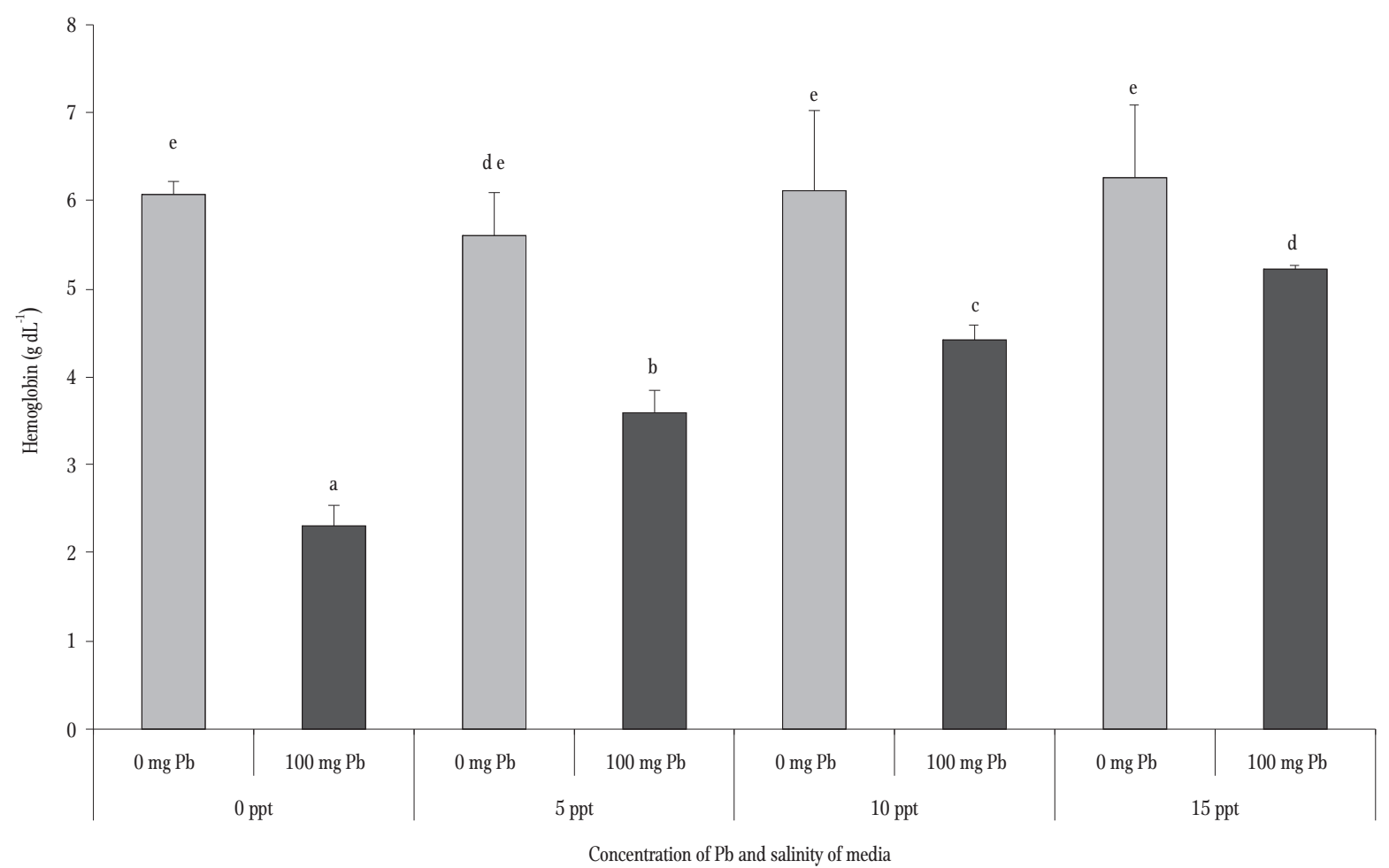

Figure 5. Hemoglobin of O. niloticus after exposure to $\mathrm{Pb}\left(0,100 \mathrm{mg} \mathrm{Pb} \mathrm{L}^{-1}\right)$ at different salinities $7 \mathrm{~d}$. Groups with different letters indicate significant differences $(\mathrm{P}<0.05, \mathrm{a}<\mathrm{b}<\mathrm{c}<\mathrm{d}<\mathrm{e})$. Data are means of five determinations. 


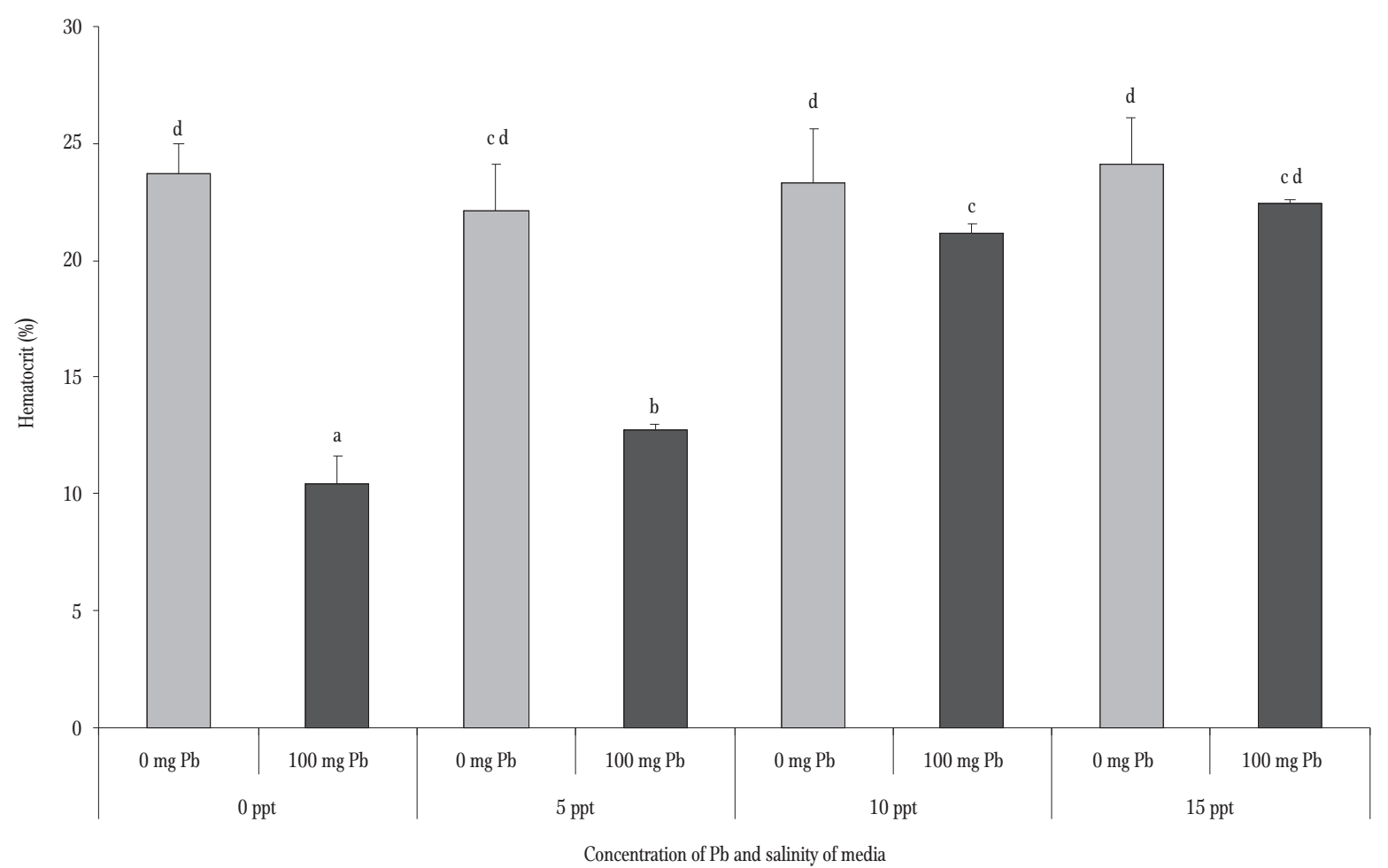

Figure 6. Hematocrit of $O$. niloticus after exposure to $\mathrm{Pb}\left(0,100 \mathrm{mg} \mathrm{Pb} \mathrm{L}^{-1}\right)$ at different salinities $7 \mathrm{~d}$. Groups with different letters indicate significant differences $(\mathrm{P}<0.05, \mathrm{a}<\mathrm{b}<\mathrm{c}<\mathrm{d})$. Data are means of five determinations.

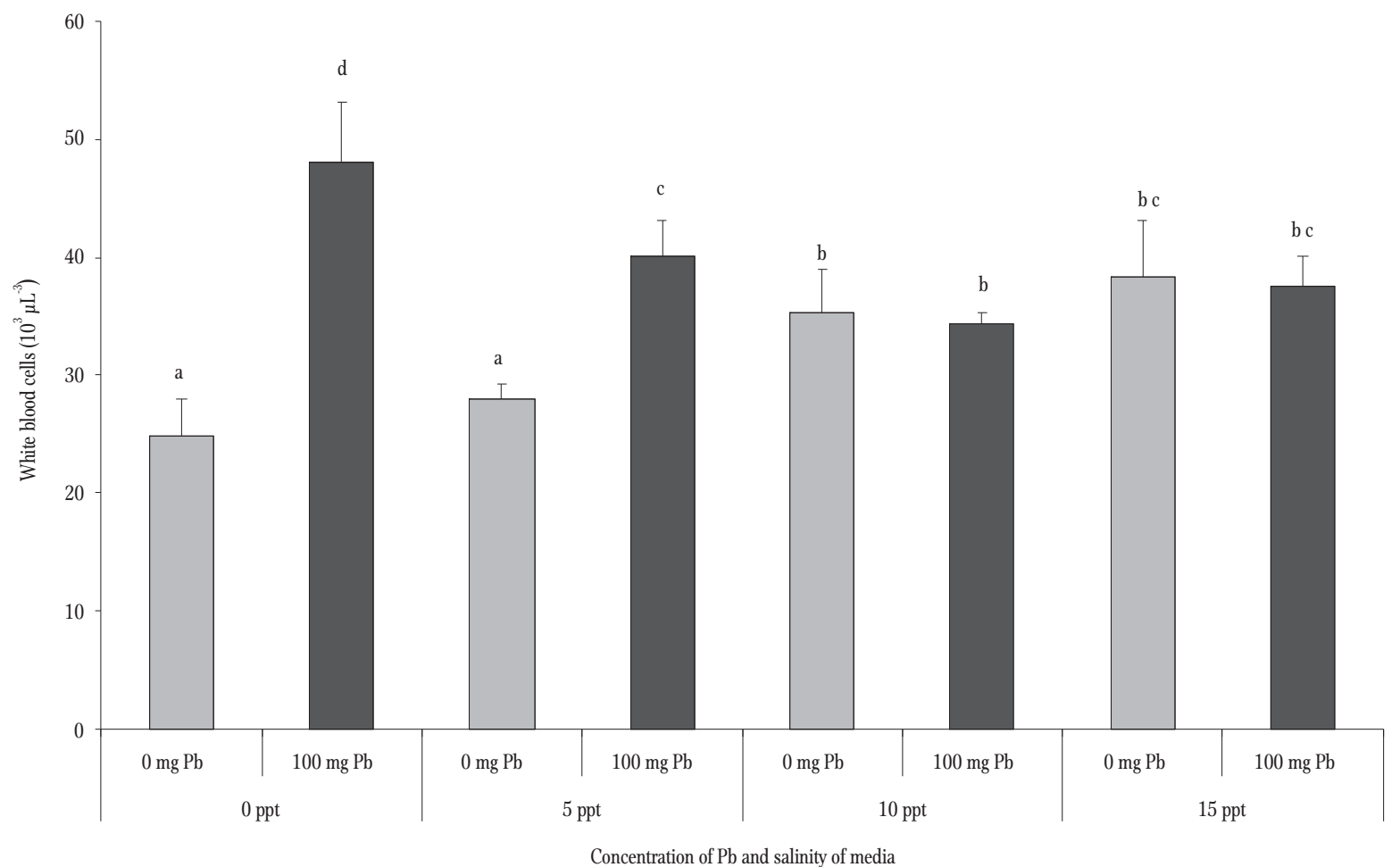

Figure 7. White blood cell counts of $O$. niloticus after exposure to $\mathrm{Pb}\left(0,100 \mathrm{mg} \mathrm{Pb} \mathrm{L}^{-1}\right)$ at different salinitiesb $7 \mathrm{~d}$. Groups with different letters indicate significant differences $(\mathrm{P}<0.05, \mathrm{a}<\mathrm{b}<\mathrm{c}<\mathrm{d})$. Data are means of five determinations. 
10 and 15 ppt without $\mathrm{Pb}$ were not significantly different, respectively. The concentrations of serum $\mathrm{Na}^{+}$in fish at 0 and 5 ppt under $\mathrm{Pb}$ exposure were not significantly different $(\mathrm{P}>0.05)$, but it increased at $10 \mathrm{ppt}$, and reached the highest level at $15 \mathrm{ppt}(\mathrm{P} \leq 0.05)$. The serum $\mathrm{Cl}^{-}$concentrations in $\mathrm{Pb}$-exposed fish increased significantly in the following order: $15 \mathrm{ppt}>10 \mathrm{ppt}>5$ ppt $>0$ ppt. The $\mathrm{Na}^{+}$levels in control and $\mathrm{Pb}$-exposed fish were not significantly different at salinity levels 0,5 , and 10 ppt. At salinity level $15 \mathrm{ppt}$, the level of $\mathrm{Na}^{+}$of $\mathrm{Pb}$-exposed fish was higher than that of the controls $(\mathrm{P}$ $\leq$ 0.05). The levels of $\mathrm{Cl}^{-}$in control and $\mathrm{Pb}$-exposed fish were not significantly different at salinity levels 0,5 , and 10 ppt respectively $(\mathrm{P}>0.05)$. The levels of $\mathrm{Cl}^{-}$of $\mathrm{Pb}$-exposed fish were significantly higher than those of the controls at salinity level 15 ppt $(\mathrm{P} \leq 0.05)$.

\section{Hematological parameters}

Significant effects of salinity, $\mathrm{Pb}$, and the interactivity between salinity and $\mathrm{Pb}$ on $\mathrm{RBC}$ counts, $\mathrm{Hb}$, and $\mathrm{Ht}$ were observed (Table 2). There were significant interactive effects between salinity and $\mathrm{Pb}$ on WBC; however, salinity level and $\mathrm{Pb}$ had no significant effect on the WBC of fish (Table 2). The levels of RBC, Hb, and $\mathrm{Ht}$ at all salinities in the control fish were not significantly different $(\mathrm{P}>0.05)$ (Figures $4,5,6)$. In $\mathrm{Pb}$-exposed fish, the levels of $\mathrm{RBC}, \mathrm{Hb}$, and $\mathrm{Ht}$ increased with the increasing salinity level of the media ( $\mathrm{P} \leq 0.05)$. At salinities 0 and $5 \mathrm{ppt}$, the levels of RBC of $\mathrm{Pb}$-exposed fish were significantly lower than those in the control $(\mathrm{P} \leq 0.05)$. Pb-exposed fish demonstrated lower levels of $\mathrm{Ht}$ and $\mathrm{Hb}$ when compared to the controls at salinity levels 0,5 , and $10 \mathrm{ppt}$ $(\mathrm{P} \leq 0.05)$. The levels of WBC of control fish and $\mathrm{Pb}$-exposed fish were not significantly different at salinity levels 10 and 15 ppt $(\mathrm{P}>0.05)$; however, their levels were significantly higher than those at 0 and 5 ppt $(\mathrm{P} \leq 0.05)$ (Figure 7). In $\mathrm{Pb}$-exposed fish, the levels of WBC decreased with increasing media salinity.

\section{Discussion}

Under normal conditions, unpolluted waters contain only trace amounts of $\mathrm{Pb}\left(0.03-0.05 \mu \mathrm{g} \mathrm{L}^{-1}\right)$; how- ever, in polluted estuaries $\mathrm{Pb}$ concentrations can reach between 10 and $25 \mathrm{mg} \mathrm{L}^{-1}$ (Fatoki and Mathabatha 2001, Yilmaz and Sadikoglu 2011). Since the $96 \mathrm{~h} \mathrm{LC}_{50}$ of $O$. niloticus fingerlings was $1.5 \mathrm{mg} \mathrm{L}^{-1}$ (Taweel et al. 2013), the Pb levels found in contaminated waters could be dangerous for the fingerlings ( $3 \mathrm{~cm}$ length, $1.5 \mathrm{~g}$ weight; Taweel et al. 2013). Studying the effects of $\mathrm{Pb}$ to the osmoregulation and hematological responses of fingerlings is more difficult than it is with adults, because of the difficulty of collecting blood samples from fingerlings. For this reason, adult $O$. niloticus were used in this study.

The $96 \mathrm{~h} \mathrm{LC}_{50}$ of $\mathrm{Pb}$ in adult $O$. niloticus in this study (200 $\mathrm{mg} \mathrm{L}^{-1}$ ) was comparable to the findings of Jiraungkoorskul et al. (2008) at $182.12 \mathrm{mg} \mathrm{L}^{-1}$ and of Kosai et al. (2011) at $182.38 \mathrm{mg} \mathrm{L}^{-1}$. In some studies, concentrations of $\mathrm{Pb}$, such as 29, 95, 300 and $820 \mathrm{mg} \mathrm{L}^{-1}$, were estimated as $96 \mathrm{~h} \mathrm{LC}_{50}$ for Carassius auratus (L.), Prochilodus lineatus (Val.), Tinca tinca (L.), and Heteropneustes fossilis (Bloch), respectively (Martinez et al. 2004, Shah 2006, Srivastav et al. 2013, Khan et al. 2014). This great variability could be attributed to species-specific responses to toxic metals (Martinez et al. 2004).

The present study used $100 \mathrm{mg} \mathrm{L}^{-1} \mathrm{~Pb}$ as the sub-lethal concentration. Although this level was higher than that found in the polluted environment, the physiological and hematological impact of sub-lethal $\mathrm{Pb}\left(100 \mathrm{mg} \mathrm{L}^{-1}\right)$ on adult fish could be experienced by fingerlings when exposed to sub-lethal $\mathrm{Pb}$ levels in their habitat. In media without $\mathrm{Pb}$, increasing salinities did not affect the SOs of $O$. niloticus, while, in contrast, the $\mathrm{SO}$ of $\mathrm{Pb}$-exposed fish increased with increasing salinity levels. There were no significant differences between the SOs of the control fish and the $\mathrm{Pb}$-exposed fish at any of the salinity levels. $\mathrm{Na}^{+}$and $\mathrm{Cl}^{-}$increased with increasing salinities in both the control and $\mathrm{Pb}$-exposed fish. As the major ions in the body fluid, $\mathrm{Na}^{+}$and $\mathrm{Cl}^{-}$(Gilles and Delpire 1997) determined blood osmolality. In $\mathrm{Pb}$-exposed fish, the $\mathrm{SO}, \mathrm{Na}^{+}$, and $\mathrm{Cl}^{-}$levels in the blood serum that increased with increasing salinity levels should be caused by the osmotically-induced removal of water from the fish and the uptake of ions 
from the hyperosmotic environment into the fish (Hwang et al. 1989, Ghahremanzadeh et al. 2014). Whereas increases of $\mathrm{Na}^{+}$and $\mathrm{Cl}^{-}$but the stable osmolality in the control fish exposed to higher salinities suggested that it is a temporary state of ion imbalance as has been reported in other fish species (Wilson and Laurent 2002, Laiz-Carrion et al. 2005). Increases of $\mathrm{Na}^{+}$and $\mathrm{Cl}^{-}$in fish following exposure to higher salinities might indicate that ion uptake mechanisms were not yet down-regulated, resulting in greater net uptake under conditions of greater $\mathrm{NaCl}$ availability (Kolbadinezhad et al. 2012). The higher levels of $\mathrm{Na}^{+}$and $\mathrm{Cl}^{-}$in $\mathrm{Pb}$-exposed fish than in the control fish at 15 ppt could be caused by greater uptake capacity with the proliferation of chloride cells, a decrease in ion efflux rates because of mucus secretion during metal exposure (Wood et al. 1988, Wood 2001), and/or a fluid shift from plasma to tissue that can occur during metal-induced stress (Wood et al. 1988, Pane et al. 2003). Chowdhury et al. (2004) report that the greater levels of plasma protein in fish provide indirect evidence of fluid loss from plasma in fish exposed to metals. Increased $\mathrm{Na}^{+}$levels and serum osmolality are also reported in the ray-finned fish $P$. lineatus after exposure to water-soluble fractions of gasoline (Simonato et al. 2013). These increases were accompanied by an increase in the quantity of chloride cells in the lamellae and of $\mathrm{N}^{+} / \mathrm{K}^{+}$-ATPase activity. They suggest that these results reflect the stimulation of the pathway to $\mathrm{Na}^{+}$uptake, as demonstrated by the activation of $\mathrm{Na}^{+} / \mathrm{K}^{+}$-ATPase activity, which resulted in an increase in $\mathrm{Na}^{+}$concentration and plasma osmolality. Other possible reasons for increased ATPase activities could be related to a period of adaptation and/or an increased number of enzyme molecules or the turnover rates of the enzyme to maintain ion flux during metal toxicity (Atli et al. 2016).

The direct effects of metals on blood parameters are usually associated with increased erythrocyte disintegration or to damage to the hemopoietic system (Svobodova et al 1994, Heath 1995). In the present study, lower RBC counts and $\mathrm{Hb}$ and $\mathrm{Ht}$ levels were noted in $\mathrm{Pb}$-exposed fish as compared to the controls at low salinity (0 and 5 ppt). Allen (1993) observed a decrease in $\mathrm{RBC}$ counts and $\mathrm{Hb}$ and $\mathrm{Ht}$ in
Oreochromis aureus (Steindachner) treated with 19 $\mathrm{mg} \mathrm{L}^{-1}$ of $\mathrm{Pb}$. Olanike et al. (2008) reported a decrease in $\mathrm{RBC}$ counts and $\mathrm{Hb}$ and $\mathrm{Ht}$ in Clarias gariepinus (Burchell) exposed to 25-200 $\mathrm{mg} \mathrm{L}^{-1}$ of $\mathrm{Pb}$. The significant decrease in the number of RBC suggested that $\mathrm{Pb}$ may inhibit $\mathrm{RBC}$ production through erythrocyte destruction (McLeay 1973). Al-Rudainy (2015) points out that the reduction in $\mathrm{Hb}$ content in fish could also be due to the inhibitory effect of $\mathrm{Pb}$ on the enzyme system responsible for $\mathrm{Hb}$ synthesis. The decrease in RBC counts coupled with the decrease in $\mathrm{Hb}$ and $\mathrm{Ht}$ is an indication that $O$. niloticus experienced anaemic conditions or hemodilution. Changes in these hematological parameters can be interpreted as a compensatory response that improves the oxygen carrying capacity to maintain gas transfer, but it also indicates a change in the water blood barrier for gas exchange in gill lamellae (Jee et al. 2005, Al-Rudainy et al. 2015). In this condition, the ability of fish to provide sufficient oxygen to the tissues is considerably restricted and will result in decreased physical activity (Wepener et al. 1992a, 1992b, Nussey et al. 1995). At higher salinities, although the RBC counts and Ht levels in $\mathrm{Cd}$-exposed fish were not significantly different from those in the control fish, the $\mathrm{Hb}$ levels of $\mathrm{Pb}$-exposed fish were lower than those in the control fish. Decreases in $\mathrm{Hb}$ might have resulted from the release of immature red blood cells with lower $\mathrm{Hb}$ content from hematopoietic tissues. Immature cells are released to compensate for the loss of RBC (Benna and Viswaranjan 1987).

A significant increase in WBC counts was noted in $\mathrm{Pb}$-exposed fish in comparison to control fish at lower salinity levels (0 and 5 ppt). Santos and Hall (1990) reported WBC increases in Anguilla anguilla (L.) subjected to $\mathrm{Pb}$ exposure, and they suggest that $\mathrm{Pb}$-induced tissue damage might have activated an immune response in the fish. Ghazaly (1991) observed an increase in $\mathrm{Pb}$ levels in blood, liver, and kidneys, which indicates that not only circulating blood leukocytes could be affected by $\mathrm{Pb}$ but that the peripheral organs could also be affected. The significant increase in WBC counts could also stem from an increase in antibody production that helps the 
survival and recovery of fish exposed to heavy metals (Joshi and Deep 2002).

\section{Conclusions}

In conclusion, our study shows that $\mathrm{Pb}$ did not change the osmolalities and caused minimum alteration in ionic regulation in tilapia, O. niloticus. Pronounced alteration occurred in the levels of the hematological parameters. At lower salinities ( 0 and 5 ppt), $\mathrm{Pb}$-exposed fish demonstrated lower levels of RBC and $\mathrm{Ht}$ and higher levels of WBC in comparison to the control fish. These hematological changes could be a compensatory and adaptive response of the fish to cope with the toxic effects of $\mathrm{Pb}$ since osmoregulation in the fish did not change. At higher salinities, the unchanged levels of RBC (at 10 and 15 ppt), Ht (at 15 ppt), and WBC (at 10 and 15 ppt) in Pb-exposed fish could indicate that salinity plays a protective role in $O$. niloticus against $\mathrm{Pb}$ intoxication.

Acknowledgments. We would like to thank the two anonymous reviewers for their critical reviews and constructive comments. This study was supported by the Kementerian Riset, Teknologi dan Pendidikan Tinggi Indonesia (Indonesian Ministry of Research, Technology and Higher Education) and Airlangga University. The authors would like to thank Mr. Setiyanto for technical assistance during the experiment.

Author contributions. M.H.A., A.Z., B.I., A.S. conceived and designed the research; M.H.A., A.Z., T.W.C.P., and A.S. performed the research; M.H.A., A.Z., and A.S. analyzed the data and wrote the paper.

\section{References}

Adeyemi J.A., Deaton L.E., Pesacreta T.C., Klerks P.L. 2012 Effects of copper on osmoregulation in sheepshead minnow, Cyprinodon variegatus acclimated to different salinities - Aquat. Toxicol. 109: 111-117.

Aldoghachi M.A., Azirun M.S., Yusoff I., Ashraf M.A. 2015 Ultrastructural effects on gill tissues induced in red tilapia Oreochromis sp. by a waterborne lead exposure Saudi J. Biol. Sci. 23: 634-641.
Allen P. 1993 - Effects of acute exposure to cadmium (II) chloride and lead (II) chloride on the haematological profile of Oreochromis aureus (Steindachner) - Comp. Biochem. Physiol. 105C: 213-217.

Al-Rudainy A.J. 2015 - Effects of sub-lethal exposure to lead acetate on haematological indices and growth rate of Bunni Mesopotamichthys sharpeyi-Adv. Anim. Vet. Sci. 3: 569-573.

Al-Rudainy A.J., Mustafa S.A., Abdulaziz M.A. 2015 - Toxic effects of mercuric chloride on DNA damage, hematological parameters and histopathological changes in common carp Cyprinus carpio - Iraq. J. Vet. Med. 38: 87-94.

Atli G., Canli E.G., Eroglu A., Dogan Z., Canli M. 2016 - Cadmium and lead alter the antioxidant and osmoregulation systems in the erythrocyte of fish (Oreochromis niloticus) - Turk. J. Fish. Aquat. Sci. 16: 361-369.

Atli G., Canli M. 2007 - Enzymatic responses to metal exposures in a freshwater fish Oreochromis niloticus - Comp. Biochem. Physiol. 145C: 282-287.

Avella M., Berhaut J., Bornancin M. 1993 - Salinity tolerance of two tropical fishes, Oreochromis aureus and Oreochromis niloticus. I. Biochemical and morphological changes in the gill epithelium - J. Fish Biol. 42: 243-254.

Baroiller J.F., Clota F., Cotta H.D., Derivaz M., Lazard J., Vergent A. 2000 - Seawater adaptability of two tilapia species (S. melanotheron and O. niloticus) and their reciprocal F1 hybrids - Proc. $5^{\text {th }}$ Inter. Symp. Tilapia in Aquaculture. Rio de Janeiro, Brazil, 3-7.10.2000, 303 p.

Benna S., Viswaranjan S. 1987 - Effect of cadmium and mercury on the hematological parameter of the fish Cyprinus carpio - Environ. Ecol. 5: 726-732.

Chowdhury M.J., Pane E.F., Wood C.M. 2004 - Physiological effects of dietary cadmium acclimation and waterborne cadmium challenge in rainbow trout: respiratory, ionoregulatory, and stress parameters - Comp. Biochem. Phys. 139C: 163-173.

Erickson R.J., Nichols J.V., Cook P.M., Ankley T. 2008 Bioavailability of chemical contaminants in aquatic systems. In: The toxicology of fishes (Eds) R.T. Di Giulio, D.E. Hinton, CRC Press, Taylor \& Francis Group, London: 9-54.

Evans D.H., Piermarini P.M., Choe K.P. 2005 - The multifunctional fish gill: dominant site of gas exchange, osmoregulation, acid-base regulation, and excretion of nitrogenous waste - Physiol. Rev. 85: 97-177.

Fatoki O.S., Mathabatha S. 2001 - An assessment of heavy metal pollution in the east London and Port Elizabeth harbours - Water SA 27: 233-240.

Fontainhas-Fernandes A., Gomes E., Reis-Henriques H., Coimbra J. 2003 - Effect of cortisol on some osmoregulatory parameters of the teleost, Oreochromis niloticus L., after transference from freshwater to seawater - Arq. Bras. Med. Vet. Zootec. 55: 562-567. 
Ghahremanzadeh Z., Namin J.I., Bani A., Hallajian A. 2014 Cytological comparison of gill chloride cells and blood serum ion concentrations in kutum (Rutilus frisii kutum) spawners from brackish (Caspian Sea) and fresh water (Khoshkrood River) environments - Arch. Pol. Fish. 22: 189-196.

Ghazaly K.S. 1991 - Influences of thiamin on lead intoxication, lead deposition in tissues and lead hematological responses of Tilapia zillii - Comp. Biochem. Physiol. 100C: 417-421.

Gilles R., Delpire E. 1997 - Variations in salinity, osmolarity, and water availability: vertebrates and invertebrates - In: Handbook of Physiology, Comparative Physiology, Vol. II. (Ed.) W. Danztler, Oxford, New York: 1523-1586.

Heath A.G. 1995 - Water pollution and fish physiology - CRC Lewis Publishers, Boca Raton, New York, London, Tokyo, $360 \mathrm{p}$.

Hwang P.P., Sun C.M., Wu S.M. 1989 - Changes of plasma osmolality, chloride concentration and gill Na-K-ATPase activity in tilapia Oreochromis mossambicus during seawater acclimation - Mar. Biol. 100: 295-299.

Jee J.H., Masroor F., Kang J.C. 2005 - Responses of cypermethrin- induced stress in haematological parameters of Korean rockfish, Sebastes schlegeli (Hilgendorf) Aquacult. Res. 36: 898-905.

Jiraungkoorskul W., Sahaphong S., Kangwanrangsan N., Zakaria S. 2008 - The protective influence of ascorbic acid against the genotoxicity of waterborne lead exposure in Nile tilapia Oreochromis niloticus (L.) - J. Fish Biol. 73: 355-366.

Joshi P., Deep H. 2002 - Effect of lindane and malathion exposure to certain blood parameters in a freshwater teleost fish Clarias batrachus - Poll. Res. 21: 55-57.

Khan S.A., Liu X., Shah B.R. 2014 - Impact of acute toxicity of lead acetate on the level of essential trace metals and histopathological changes in Crucian carp (Carassius auratus gibelio) - J. Anim. Plant Sci. 24: 1405-1414.

Khangarot B.S., Tripathi D.M. 1991 - Changes in humoral and cell-mediated immune responses and in skin and respiratory surfaces of catfish, Saccobranchus fossilis, following copper exposure - Ecotox. Environ. Safe. 22: 291-308.

Kolbadinezhad S.M., Hajimoradloo A., Ghorbani R., Joshaghani H., Wilson J.M. 2012 - Effects of gradual salinity increase on osmoregulation in Caspian roach Rutilus caspicus - J. Fish Biol. 81: 125-134.

Kosai P., Jiraungkoorskul W., Synsatayakul A., Jiraungkoorskul K. 2011 - Efficacy of calcium reducing lead toxicity in hematology of Oreochromis niloticus - J. Fish. Aquat. Sci. 6: 346-355.

Laiz-Carrion R., Guerreiro P.M., Fuentes J., Canario A.V.M., Martin del Rio M.P., Mancera J.M. 2005 - Branchial osmoregulatory response to salinity in the gilthead sea bream, Sparus auratus - J. Exp. Zool. 303A: 563-576.
Lauren D.J., McDonald D.G. 1985 - Effects of copper on branchial ionoregulation in the rainbow trout, Salmo gairdneri Richardson. Modulation by water hardness and pH - J. Comp. Physiol. 155: 635-644.

Lauren D.J., McDonald D.G. 1986 - Influence of water hardness, $\mathrm{pH}$, and alkalinity on the mechanisms of copper toxicity in juvenile rainbow trout, Salmo gairdneri - Can. J. Fish. Aquat. Sci. 43: 1488-1496.

Lock R.A.C., Cruissen P. M. J. M., Van Overbeeke A.P. 1981 Effects of mercuric chloride and methylmercuric chloride on the osmoregulatory function of the gills in rainbow trout, Salmo gairdneri Richardson - Comp. Biochem. Physiol. 68C: 151-159.

Loro V.L., Jorge M.B., daSilva K.R., Wood C.M. 2012 - Oxidative stress parameters and antioxidant response to sublethal waterborne zinc in a euryhaline teleost Fundulus heteroclitus: Protective effects of salinity Aquat. Toxicol. 110-111: 187-193.

Martinez C.B.R., Nagae M.Y., Zaia C.T.B.V., Zaia D.A.A. 2004 - Acute morphological and physiological effects of lead in the neotropical fish Prochilodus lineatus - Braz. J. Biol. 64: 797-807.

McLeay D.J. 1973 - Effects ACTH on the pituitary-interrenal axis and abundance of white blood cell types in juvenile coho salmon, Oncorhynchus kisutch - Gen. Comp. Endocr. 21: 431-440.

Mohseni M., Ozorio R.O.A, Pourkazemi M., Bai S.C. 2008 Effects of dietary L-carnitine supplements on growth and body composition in beluga sturgeon (Huso huso) juveniles - J. Appl. Ichthyol. 24: 646-649.

Nussey G., Van Vuren J.H.J, du Preez H.H. 1995 - Effect of copper on haematology and osmoregulation of the Mozambique tilapia, Oreochromis mossambicus (Cichlidae) - Comp. Biochem. Physiol. 111C: 369-380.

Olanike K., Funmilola A., Olufemi B., Olajide O. 2008 Acute toxicity and blood profile of adult Clarias gariepinus exposed to lead nitrate - Internet J. Hematol. 4: 1-10.

Pane E.F., Richards J.G., Wood C.M. 2003 - Acute waterborne nickel toxicity in the rainbow trout (Oncorhynchus mykiss) occurs by a respiratory rather than ionoregulatory mechanism - Aquat. Toxicol. 63: 65-82.

Putranto T.W.C., Andriani R., Munawwaroh A. Irawan B., Soegianto A. 2014 - Effect of cadmium on survival, osmoregulation and gill structure of the Sunda prawn, Macrobrachium sintangense (de Man), at different salinities - Mar. Freshw. Behav. Physiol. 47: 349-360.

Rainbow P.S. 1995 - Physiology, physicochemistry and metal uptake - a crustacean perspective - Mar. Pollut. Bull. 31: 55-59.

Ramesh M., Saravanan M., Kavitha C. 2009 - Hormonal responses of the fish, Cyprinus carpio, to environmental lead exposure - Afr. J. Biotechnol. 8(17): 4154-4158. 
Roast S.D., Widdows J., Jones M.B. 2001 - Effects of salinity and chemical speciation on cadmium accumulation and toxicity to two mysid species - Environ. Toxicol. Chem. 20: 1078-1084.

Santos M.A., Hall A. 1990 - Influence of inorganic lead on the biochemical blood composition of the eel, Anguilla anguilla L. - Ecotox. Environ. Safe. 20: 7-9.

Scott G.R., Sloman K.A. 2004 - The effects of environmental pollutants on complex fish behaviour: integrating behavioural and physiological indicators of toxicity - Aquat. Toxicol. 68: 369-392.

Shah S.L. 2006 - Hematological parameters in tench Tinca tinca after short term exposure to lead - J. Appl. Toxicol. 26: 223-228.

Simonato J.D., Fernandes M.N., Martinez C.B.R. 2013 Physiological effects of gasoline on the freshwater fish Prochilodus lineatus (Characiformes: Prochilodontidae) Neotrop. Ichthyol. 11: 683-691.

Spry D.J., Wood C.M. 1985 - Ion flux rates, acid-base status, and blood gases in rainbow trout, Salmo gairdneri, exposed to toxic zinc in natural soft water - Can. J. Fish. Aquat. Sci. 42: 1332-1341.

Srivastav A.K., Rai R., Suzuki N., Mishra D., Srivastav S.K. 2013 - Effects of lead on the plasma electrolytes of a freshwater fish, Heteropneustes fossilis - Inter. Aquat. Res. (IAR), 5: 4.

Suresh A.V., Lin C.K. 1992 - Tilapia culture in saline waters: a review - Aquaculture 106: 201-226.

Svobodova Z., Vykusova B., Machova J. 1994 - The effects of pollutants on selected haematological and biochemical parameters in fish - In: Sublethal and chronic effects of pollutants on freshwater fish (Eds) R. Muller, R. Lloyd, Fishing New Books, London: 39-52.

Taweel A., Shuhaimi-Othman M., Ahmad A.K. 2013 - In vivo acute toxicity test of some heavy metals to tilapia fish
(Oreoshromis niloticus) - Pak. J. Biol. Sci. DOI: 10.3923/pjbs.2013.

Verbost P.M., Flik G., Lock R.A.C., Wendelaar Bonga S.E. 1987 - Cadmium inhibition of $\mathrm{Ca}^{2+}$ uptake in rainbow trout gills - Am. J. Physiol. 253: R216-R221.

Viale G., Calamari D. 1984 - Immune response in rainbow trout Salmo gairdneri after long-term treatment with low levels of Cr, Cd and Cu - Environ. Pollut. 35A: 247-257.

Viola A., Pregnolato G., Albergoni V. 1996 - Effect of in vitro cadmium exposure on natural killer (NK) cells of catfish, Ictalurus melas - Fish Shellfish Immun. 6: 167-172.

Wendelaar Bonga S.E., Lock R.A.C. 1992 - Toxicants and osmoregulation in fish - Neth. J. Zool. 42: 478-493.

Wepener V., van Vuren J.H.J., Du Preez H.H. 1992a - The effect of hexavalent chromium at different $\mathrm{pH}$ values on the haematology of Tilapia sparrmanii (Cichlidae) Comp. Biochem. Physiol. 101C: 275-381.

Wepener V., Van Vuren J.H.J, Du Preez H.H. 1992b - Effect of manganese and iron at a neutral and acidic $\mathrm{pH}$ on the hematology of the banded tilapia (Tilapia sparrmanii) Bull. Environ. Contam. Toxicol. 49: 613-619.

Wilson J.M., Laurent P. 2002 - Fish gill morphology: inside out - J. Exp. Zool. 293: 192-213.

Witeska M. 2005 - Stress in fish - hematological and immunological effects of heavy metals - Electron J. Ichthyol. 1: 35-41.

Wood C.M. 2001 - Toxic responses of the gill - In: Target organ toxicity in marine and freshwater teleosts: Organs (Eds) D. Schlenk, W.H. Benson, CRC Press, London, 382 p.

Wood C.M., Simons B.P., Mount D.R., Bergman H.L. 1988 Physiological evidence of acclimation to acid/aluminum stress in adult brook trout (Salvelinus fontinalis): 2. Blood parameters by cannulation - Can. J. Fish. Aquat. Sci. 45: 1597-1605.

Yilmaz S., Sadikoglu M. 2011 - Study of heavy metal pollution in seawater of Kepez harbor of Canakkale (Turkey) Environ. Monit. Assess. 173: 899-904. 